\title{
Effect of Convective Drying Method of Chokeberry (Aronia melanocarpa L.) on Drying Kinetics, Bioactive Components and Sensory Characteristics of Bread with Chokeberry Powder
}

\author{
Marko Petkovićn ${ }^{\star}$, Igor Đurović1, Nemanja Miletić ${ }^{1}$, Jovana Radovanović ${ }^{1}$ \\ 1 Department of Food Technology, Faculty of Agronomy, University of Kragujevac, Cara Dušana 34, 32000 Čačak, Serbia \\ * Corresponding author, e-mail: marko.petkovic@kg.ac.rs
}

Received: 23 January 2019, Accepted: 23 April 2019, Published online: 23 May 2019

\begin{abstract}
The effects of three dehydration temperatures at 50,60 and $70^{\circ} \mathrm{C}$ of convective drying method on fresh fruits of black chokeberries (Aronia melanocarpa L.) were evaluated. The drying temperatures were found to have significantly different effects on the characteristics of dried fruits and powders, made by the dried fruits. The maximum drying rate at a temperature of $50{ }^{\circ} \mathrm{C}$ was $59 \mathrm{~g} / \mathrm{h}$, at $60{ }^{\circ} \mathrm{C}$ $102 \mathrm{~g} / \mathrm{h}$, and at $70^{\circ} \mathrm{C} 115 \mathrm{~g} / \mathrm{h}$, and thus the drying time was 37 hours, 27 hours and 23 hours respectively. The drying temperature at $50{ }^{\circ} \mathrm{C}$ caused the least damage to the cell structure of the fresh chokeberries, bioactive components (anthocyanins, flavonoids, phenols) and total antioxidativity. The dehydrated chokeberries at the temperature of $50{ }^{\circ} \mathrm{C}$ had the highest ratio of total anthocyanins (376.89 \pm 5.73 mg cyn-3-glu / 100 g dm), total flavonoids (1037.19 \pm 3.83 mg CE / 100 g dm), phenols (1918.79 \pm 3.26 mg GAE / 100 g dm) and antioxidant activity $(37.11 \pm 0.28 \mathrm{mg}$ TE / $100 \mathrm{~g} \mathrm{dm})$. The drying process at a temperature of $50{ }^{\circ} \mathrm{C}$ required longer drying period, higher energy need and produced the chokeberry powder, which gave the bread with the best sensory characteristics, compared to a drying process at a temperature of $60^{\circ} \mathrm{C}$ and $70^{\circ} \mathrm{C}$.
\end{abstract}

Keywords

convective dehydration, antioxidants, fruit powder, bread, sensory characteristics

\section{Introduction}

Black chokeberry (Aronia melanocarpa L.) belongs to the Rosaceae family. It may be a deciduous bush found in damp woods and swamps. Its dark berries are comparable to dark currents with a really astringent enhance [1]. The advantageous impacts of chokeberry have been proposed to be ascribed to polyphenols. Polyphenols contribute to health benefits due to its strong antioxidative ability, such as free radical scavenging, oxygen radical absorbance, and chelation of metal ions. They reduce the level of low-density lipoprotein (LDL) cholesterol in the blood, preventively acting on cardiovascular diseases, reducing the glucose level in the blood, diabetes and gastrointestinal protection [2, 3]. Because of polyphenols (tannins, phenolic acids, and bitter eriodictyol glucuronide), black chokeberry has a bitter and a tart taste [4]. Bioactive components of chokeberry are four anthocyanins, nine flavonoids, two phenolic acids and five quercetins [1]. Total flavonoids content ranging from 3.73 in chokeberry juice, through 7.85 in fruits to $10.58 \mathrm{~g} \mathrm{CE} / 100 \mathrm{~g}$ dry matter $(\mathrm{dm})$ in pomace $[5,6]$.

One of the fruit products is fruit powders, obtained after the drying process of fresh fruit or juice. Fruit powders are commonly used as intermediates, natural food colorants and supplements [7]. Among the drying techniques, the most commonly used in the food industry is the traditional convection air drying method. This method is a longtime performance. Dried products have low porosity and quality, compared to the fresh products. Drying process causes changes in the quality and quantity of bioactive compounds and their antioxidant capacity [8]. The quality of dehydrated products is defined by physical (texture, appearance, porosity, color) and chemical characteristics (residual nutrients from fresh fruit) [9, 10].

Bread, containing bioactive antioxidants, such as caffeic acid, quercetin, procyanidin and anthocyanins might 
be important consumers demand [11]. The bioactive components (antioxidants) in bread may be protected by binding to wheat proteins during or degradation / oxidation of dough formation. Added bioactive components may result in a dilution of gluten (wheat protein), causing reduced loaf volume, because of altered cross-linking [12].

In this study, comparative evaluations on the sensory properties of bread with and without chokeberry powders were analyzed, based on physical and chemical properties (convective drying, solid dry content and acidity, rehydration ratio and water absorption capacity), and properties of bioactive components (anthocyanins, flavonoids, phenols, antioxidant activity) of dried and ground chokeberries, as a wheat powder substitute.

\section{Experimental}

Fruits of chokeberry (black aronia, Aronia melanocarpa L.) were collected in August 2018, from the village Kušići, located on Javor mountain $\left(43^{\circ} 28^{\prime} 40.8^{\prime \prime} \mathrm{N}\right.$, $20^{\circ} 03^{\prime} 35.7^{\prime \prime E}$, Serbia) and stored in the refrigerator at a temperature of $+4^{\circ} \mathrm{C}$, for no longer than 3 days. The ethanol extracts were prepared from fresh and dried fruits. Fruits were dissolved in $96 \%$ ethanol, slightly milled and placed in the ultrasonic bath (VabSonic, SB-1,5L SH, Serbia) for 30 minutes, filtered, placed in small jars and stored in a refrigerator. A total of seven samples were prepared (fresh fruits, fruits dried at 50, 60 and $70{ }^{\circ} \mathrm{C}$ and fruit extracts from the fruits dried at 50, 60 and $70{ }^{\circ} \mathrm{C}$ ). Dried fruits and fruit extracts were stored in the refrigerator at a temperature of $+4{ }^{\circ} \mathrm{C}$, for no longer than 10 days.

\subsection{Experimental drying process}

The uncrushed berries were dried by a convective method in a dehydrator (Colossus CSS 5330, PRC) at temperatures of 50,60 and $70{ }^{\circ} \mathrm{C}$ at atmospheric pressure, to the constant weight. Drying of uncrushed fruit will keep a higher level of antioxidant bioactive components (especially anthocyanins), then drying the crushed fruits [13]. The dehydrator is a vertical device, with a central fan (power $250 \mathrm{~W}$ at $220 \mathrm{~V}$ and constant $0.25 \mathrm{~ms}^{-1}$ air drying velocity) and top perforated cover. Three series of fresh fruits $(1200 \pm 0.1 \mathrm{~g})$ were measured and divided into five plastic perforated layers $(32 \mathrm{~cm}$ in diameter), each one consisting of $240 \mathrm{~g}$ fruit $(5 \times 240 \mathrm{~g}$ $=1200 \mathrm{~g}$ ). Dried fruits were milled in a grinder (Delimano Chopper, Switzerland, power $200 \mathrm{~W} / 50 \mathrm{~Hz}$ ) and powders were obtained. The milling process was short and pulsed (30 seconds of milling, 60 seconds of stabilization).
The drying kinetics was based on mass losses of chokeberry [14]. The moisture ratio $(M R)$ is defined according to Eq. (1):

$$
M R=\frac{M_{t}-M_{e}}{M_{o}-M_{e}} .
$$

$M_{t}, M_{o}$ and $M_{e}$ denote moisture content achieved after drying time $t$, initial moisture content, and equilibrium moisture content, respectively. The value of equilibrium moisture content $\left(M_{e}\right)$ usually is very low and can be omitted from Eq. (1) without a significant change in the value of $M R$.

The drying kinetics could be also expressed as a change in the total mass of fruits $\left(M_{i-1}-M_{i}\right)$ in the interval of time between 2 measurements $\left(t_{i-1}-t_{i}\right)$ on a particular tray during the drying process (drying ratio, $D R$ ) [15].

\subsection{Soluble solid content, dry matter content and acidity}

The soluble solid content (SSC) of the fruit was determined on a manual refractometer (3828 Carl Zeiss, Germany). The dry matter content $(D M C)$ was determined by drying the fruit at $105^{\circ} \mathrm{C}$ until a constant mass (Sutjeska, Serbia). The acidity ( $\mathrm{pH}$ values) of fresh fruit was determined with pH meter (CyberScan CON 510, Eutech, The Nederlands), directly in the fruit juice. Dried fruits were milled and dissolved (25\% solution) in distilled water, placed in a boiling water bath for 30 minutes, cooled under the cold water and eventually, the $\mathrm{pH}$ values were determined [16].

\subsection{Total anthocyanins, flavonoids, phenols and antioxidant activity}

Total anthocyanins content $(T A C)$ of extracts was determinate using the $\mathrm{pH}$-differential method. The values are expressed as milligrams of cyanidin-3-glucoside equivalents per $100 \mathrm{~g}$ dry matter using a molar extinction coefficient of 26900 and the molecular weight of $449.2 \mathrm{~g} / \mathrm{mol}$ [17]. Total flavonoids content (TFC) of extracts was determined by a colorimetric method [18]. The results are expressed as milligrams of catechin equivalents per $100 \mathrm{~g}$ dry matter (mg CE / $100 \mathrm{~g} \mathrm{dm}$ ). Total phenols content (TPC) of extracts was determined by a modified Folin-Ciocalteu colorimetric method, with results expressed as milligrams of gallic acid equivalents per $100 \mathrm{~g}$ dry matter (mg GAE / $100 \mathrm{~g} \mathrm{dm}$ ) [19]. Antioxidant activity (antioxidant capacity, AA) was measured by the DPPH assays. Results were expressed as Trolox equivalent antioxidant capacity (mg TE per $100 \mathrm{~g} \mathrm{dm}$ ) [19]. 


\subsection{Rehydration ratio and water absorption capacity}

Rehydration experiments were carried out in distilled water at room temperature. Dried fruits $(4 \mathrm{~g})$ were added to $100 \mathrm{ml}$ of distilled water and mixed thoroughly. The samples were rehydrated for 24 hours, and the rehydration temperature was kept constant. At the end of the rehydration process, the unabsorbed water was decanted, and the weight and moisture content were determined. The rehydration ratio $\left(R_{r}\right)$ was expressed as a ratio of water absorbed by the dried fruits $(\mathrm{g})$ to the weight of the dried fruits $(\mathrm{g})$.

The coefficient of rehydration $\left(C_{r}\right)$ is water absorption during the rehydration process [20]. $W_{r}$ is the weight of rehydrated fruits, $W_{d}$ the weight of the dried sample, $A$ the moisture of fresh fruits (\% wet matter) and its moisture is about $1 \%\left(W_{u}\right)$. The coefficient of rehydration $\left(C_{r}\right)$ is calculated by Eq. (2):

$$
C_{r}=\frac{W_{r} \cdot(100-A)}{W_{d}-W_{d} \cdot \frac{W_{u}}{100}} .
$$

\subsection{Method of laboratory bread baking}

The amount of powder, yeast, salt, and other ingredients was mixed in a Diosna-type mixer (Colossus CSS5406, PRC) for 3 minutes. The dough was removed from the mixer, measured, shaped and fermented in a thermostat at $30{ }^{\circ} \mathrm{C}$ for 90 minutes, with occasional re-mixing [21]. After the fermentation process was finished, the dough was split, shaped and placed on a canvas in a knitted basket, for final fermentation. The final fermentation was carried out in a thermostat at $30{ }^{\circ} \mathrm{C}$ and relative humidity of $75 \%$, for 50 minutes. The bread was baked in the laboratory oven at $220-250{ }^{\circ} \mathrm{C}$ for about 20 minutes. The working space in the laboratory oven was saturated with steam. When the baking process was finished, the baked bread was placed on a wooden grid to cool down and wrapped in aluminum foil and left for 24 hours at room temperature, prior to sensory evaluation of bread quality after 24 hours.

Composition of bread ingredients was as follows: wheat flour type T400 (total ash $\leq 0.45 \%$, total water $\leq 5 \%$ ) $100 \%$, dried chokeberry powder $(10 \%+90 \%$ wheat flour type T400), crystal sugar (sucrose, $1.50 \%$ ) salt (1.85\%), fresh yeast Saccharomyces cerevisiae, $3.0 \%$ ), palm fat $(1.85 \%)$ and distilled water (58.0\%).

\subsection{Method of sensory evaluation of bread quality}

Sensory evaluation of bread quality $(500 \pm 0.1 \mathrm{~g}$ of bread sample) was determined by scoring and QDA method [21, 22], by a panel of six trained evaluators. Evaluators identified descriptors and scored taste using a 6-point scale $(0-$ not detected, 5 - strong). QDA method is qualitative descriptive analysis method which involves evaluating (from 1 to $5,0.5$ increments) individual quality parameters and their input into polar coordinates. The combination of five evaluated labels determined the quality diagram of bread.

\subsection{Statistics}

All samples were analyzed triplicates. The results are expressed as mean values \pm standard deviation (SD). Differences were considered significant if $P$-values were under 0.05. Statistical analysis of experimental data was performed using the Statistica (Tukey HSD Test), [23].

\section{Results and discussion}

\subsection{Effects of drying temperature on the quality parameters of chokeberry}

The moisture content of fresh chokeberry was $3.65 \pm 0.3 \mathrm{~g} / \mathrm{g} \mathrm{dm}$ (dry matter). The Henderson \& Pabis exponential model was one of the best models [14, 24] to predict the mass losses of chokeberry samples dehydrated by convective drying at 50, 60 and $70{ }^{\circ} \mathrm{C}$ (Eq. (3), Fig. 1 (a)). The drying kinetics could be also precisely predicted by the GaussMod function (Fig. 1 (b), Eq. (4)). Parameters of models, describing the drying kinetics of chokeberries using all these protocols, were summarized in Table 1.

$M R=a \cdot e^{k \cdot t}$

where $a, n$, and $k$ are constants.

$D R=y_{0}+\frac{A}{t_{0}} e^{\frac{1}{2} \cdot\left(\frac{\omega}{t_{0}}\right)^{2} \cdot \frac{x-x_{c}}{t_{0}}} \int_{-\infty}^{z} \frac{1}{2 \pi} e^{\frac{-y^{2}}{2}} d y, \quad z=\frac{x-x_{c}}{w}-\frac{w}{t_{0}}$

where $y_{o}, A, x_{c}, w$, and $t_{o}$ are constants.

The good fitting of a specific model to the experimental data was evaluated using the coefficient of determination $\left(R^{2}\right)$ and root mean square error $(R M S E)$. The model fit is better if the value of $R^{2}$ is closer to unity and the $R M S E$ value is closer to 0 .

In the initial stage of convective drying, a fast loss of water was observed, regardless of the drying temperature applied (Fig. 1). The second stage caused a reduction in the speed of water removal from chokeberry samples due to a significantly lower drying rate. All three curves had the same shape, with different drying time to a constant mass. Drying time (Fig. 1 (a)) depended directly on the temperature of drying, and thus the drying time was 37, 27 and 23 hours, respectively. Namely, if the temperature of the drying process was 

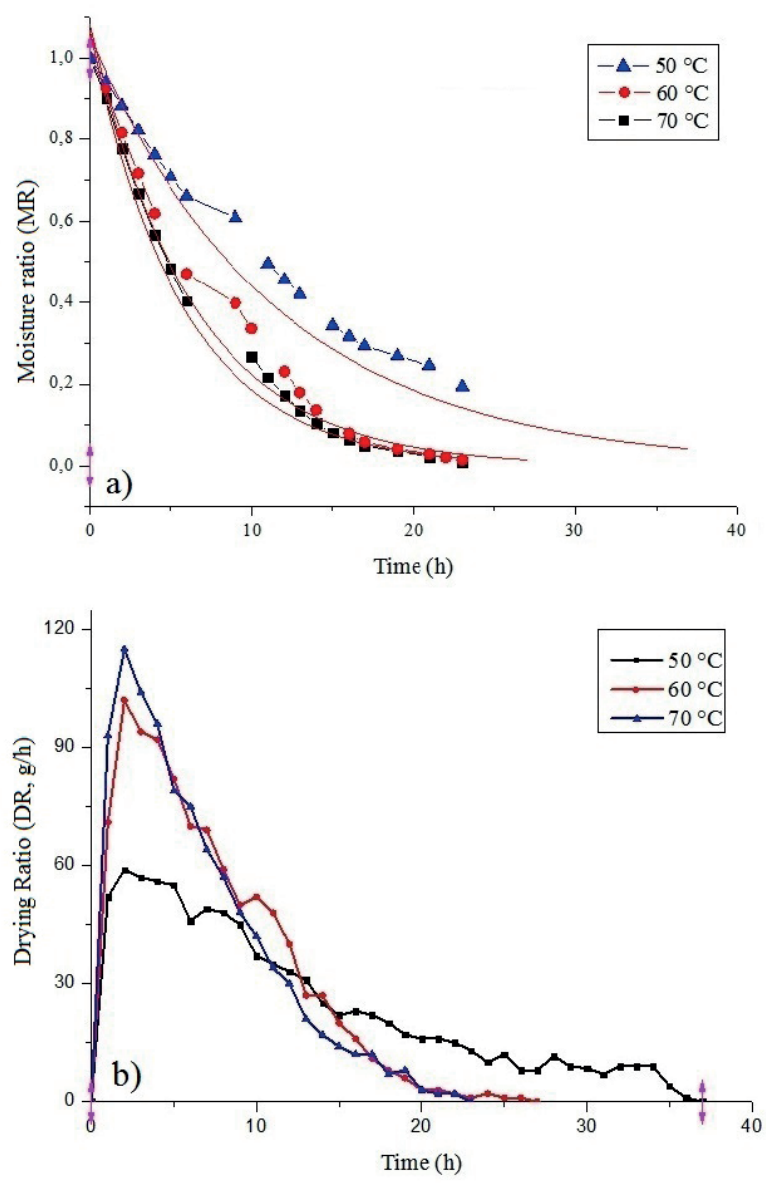

Fig. 1 Effects of drying temperature on the moisture ratio (a) and drying ratio (b)

increased, the partial pressure of the water vapor on the surface of the fruit was increased as well, resulting in a faster diffusion of water from the interior towards the surface of the fruits. The maximum $D R$ was achieved in the second hour of the drying process, regardless the temperature, and at a temperature of $50{ }^{\circ} \mathrm{C}$ was $59 \mathrm{~g} / \mathrm{h}(M R=0.2287 \mathrm{~g} / \mathrm{g} \mathrm{dm})$, at $60{ }^{\circ} \mathrm{C} 102 \mathrm{~g} / \mathrm{h}(M R=0.3953 \mathrm{~g} / \mathrm{g} \mathrm{dm})$, and at $70{ }^{\circ} \mathrm{C} 115 \mathrm{~g} / \mathrm{h}$ $(M R=0.4457 \mathrm{~g} / \mathrm{g} \mathrm{dm})$.

This decrease in the drying time agreed with an increase in the drying constant $k$ of the Henderson \& Pabis model, from -0.1577 to -0.1748 (Table 1), as in research by Szychowski et al. [14]. The drying constant $a$ varied slightly and had values that were closed to 1 .
The Henderson \& Pabis model was found as a good model taking into account the highest values of $R^{2}$ (means of 0.9937, 0.9866 and 0.9909 , respectively) and the lowest values of $R S M E$ ( $0.0173,0.0325$ and 0.0187 , respectively).

The equilibrium of dry / moisture contents during the drying process depends on drying temperature. The slope of the drying curve (Fig. 1 (b)), at the drying temperature of $50{ }^{\circ} \mathrm{C}$, was the lowest and occurred after 16 hours of the drying process. Increasing the drying temperature to 60 and $70{ }^{\circ} \mathrm{C}$ resulted in a greater slope in the drying curves, with equilibrium content of dry matter and water after 9 and 8 hours, respectively. Increase in a drying temperature agreed with the increase of the drying constants $A, x_{c}$, and $w$, and the decrease of the drying constants $y_{o}$ and $t_{o}$ of the GaussMod model, as in research by Mitrović et al. [15]. The GaussMod model was found as a good model taking into account the highest values of $R^{2}$ (means of 0.9789 , 0.9856 and 0.9957 , respectively) and the lowest values of $R S M E$ (0.0247, 0.0221 and 0.0196, respectively).

\subsection{Soluble solid content, dry matter content and acidity} Total dry matter in fresh chokeberries was $21.48 \pm 0.21 \%$, which was approximated to the results of $22 \%$ of total dry matter, as in research by Liepina et al. [25]. The content of soluble dry matter in fresh fruits was $17.71 \pm 0.38 \%$ and depended on the variety of chokeberry and cultivation. The higher content of soluble dry matter was explained by the higher amount of present soluble compounds (sugar, acid) as opposed to insoluble substances (cellulose). Total insoluble dry matter in fresh chokeberries was $3.87 \pm 0.10 \%$.

Acidity $(\mathrm{pH})$ of fresh chokeberries and chokeberry dried at 50, 60 and $70{ }^{\circ} \mathrm{C}$ were $3.41 \pm 0.05^{\mathrm{a}}, 3.41 \pm 0.04^{\mathrm{a}}$, $3.41 \pm 0.05^{\mathrm{a}}$ and $3.41 \pm 0.06^{\mathrm{a}}$, respectively. Based on the analysis of the $\mathrm{pH}$ of the dried chokeberry powders, the ANOVA and the following post-hoc Tukey's HSD test showed that the different temperatures of the drying process of chokeberry had no influence on fresh and dried chokeberries acidity. Liepinga et al. [25] for an aqueous extract of fresh chokeberries indicated $\mathrm{pH}$ value of 3.2, while for aqueous extracts of dried fruits, the value was 3.8. Deviations in results could be explained by different ways of preparing extracts, different

Table 1 Mathematical model of effects of drying temperature on the moisture ratio $(M R)$

\begin{tabular}{|c|c|c|c|c|c|c|c|c|c|c|c|}
\hline \multirow{2}{*}{ Drying temperature $\left({ }^{\circ} \mathrm{C}\right)$} & \multicolumn{4}{|c|}{ The Henderson \& Pabis parameters } & \multicolumn{7}{|c|}{ The GaussMod parameters } \\
\hline & $a$ & $k$ & $R^{2}$ & $R S M E$ & $y_{o}$ & $A$ & $x_{c}$ & $w$ & $t_{o}$ & $R^{2}$ & $R S M E$ \\
\hline 50 & 1.0548 & -0.0871 & 0.9937 & 0.0173 & -5.2773 & 1230.0470 & 0.6415 & 0.4416 & 16.5061 & 0.9789 & 0.0247 \\
\hline 60 & 1.0617 & -0.1577 & 0.9866 & 0.0325 & -21.7382 & 1757.7061 & 0.7000 & 0.7026 & 12.0650 & 0.9856 & 0.0221 \\
\hline 70 & 1.0671 & -0.1748 & 0.9909 & 0.0187 & -15.5599 & 1427.7618 & 0.6594 & 0.5253 & 9.1999 & 0.9957 & 0.0196 \\
\hline
\end{tabular}


varieties, in agro-technical measures and the underlying area where the tested chokeberry was grown [26].

\subsection{Total anthocyanins, flavonoids, phenols and antioxidant activity}

The content of antioxidants was determinate by the procedure of fruit preparation for processing [13]. An analysis of variance showed that the total contents of the identified bioactive components among the three dried-group of chokeberries were significantly different $(p<0.05)$. Total anthocyanins, flavonoids, and phenols content and antioxidant activity of fresh and chokeberries dried at 50,60 and $70{ }^{\circ} \mathrm{C}$ are shown in Table 2. The highest loss of total anthocyanins content $(80 \%)$ were in chokeberries during convective drying at $60{ }^{\circ} \mathrm{C}$, while vacuum-drying or vacuum-microwave drying kept more than $50 \%$ of total anthocyanins [27]. Anthocyanins are highly thermolabile, and therefore thermal treatments of dehydration extremely reduced the total anthocyanins in the chokeberry extracts. As expected, the highest content of total anthocyanins was determined in the extract of fresh chokeberries (1764.9 $\pm 25.16 \mathrm{mg}$ cyn-3glu / $100 \mathrm{~g} \mathrm{dm}$ ). The reducing ratio of total anthocyanins, as a result of a different drying temperature of 50, 60 and $70{ }^{\circ} \mathrm{C}$, is about $21: 4,5: 1,5: 1$, respectively. Anthocyanins are mainly concentrated in fruits' skin [13]. Their migration from fruit skin into the fruit mesocarp was determined, most of all, by skin damage, i.e. the appropriate method of fruit crushing and damaging the cell walls.

High temperatures of dehydration process reduced the total flavonoids in the chokeberry extracts. Extracts of fresh chokeberries had the highest content of total flavonoids (2346.31 $\pm 13.66 \mathrm{mg} \mathrm{CE} / 100 \mathrm{~g} \mathrm{dm})$. Therefore, anthocyanins were more thermolabile than flavonoids on the dehydration process at 50,60 and $70^{\circ} \mathrm{C}$. The reducing ratio of total flavonoids in fresh chokeberries, as a result of a different drying temperature of 50, 60 and $70{ }^{\circ} \mathrm{C}$, was about $3: 1$, $5: 1,5: 1$, respectively. These studies are in agreement with Ioannou and Ghoul [28]. The type and content of plant bioactive components can be also influenced by maturity [29].
Freeze-dried chokeberry had a loss in $9 \%$ of total phenolics [27]. Powder chokeberry, after oven-vacuum drying, had a slightly lower content of total polyphenols [26]. The highest amount of total phenols was found in the extract of fresh chokeberries (5222.54 $\pm 3.43 \mathrm{mg} \mathrm{GAE} / 100 \mathrm{~g} \mathrm{dm})$. The application of drying processes caused changes between total phenols in the produced powders. The reducing ratio of phenolics in fresh chokeberries, as a result of a different drying temperature of 50,60 and $70^{\circ} \mathrm{C}$, was about $4,45: 1$, $65: 1,15: 1$, respectively. The extreme reduction values of total phenolics, caused by thermodegradation of the drying process, were in a correlation to total anthocyanins and flavonoids. The variety of chokeberries, and climatic conditions of chokeberry cultivation, as well as the method of powders preparation, showed a major effect on total phenolics [30].

Convention drying leads to the degradation of bioactive compounds that are strongly dependent on the drying method [28]. The degradation of total anthocyanins was $80-90 \%$, total flavonoids about $50 \%$ and total phenols about $65-75 \%$.

The antioxidant capacities of the fresh and dried extracts were determined by the $\mathrm{DPPH} \bullet$ assay. Antioxidant capacity strongly depends on the properties of bioactive components present in the fruit samples [31]. The results presented in Table 2 indicate the differences in the antioxidant capacity the analyzed samples. Antioxidant activity was pronounced the most in fresh chokeberries $(112.14 \pm 2.91 \mathrm{mg}$ TE $/ 100 \mathrm{~g}$ dry matter). The reducing ratio of antioxidant activity, as a result of a different drying temperature of 50,60 and $70{ }^{\circ} \mathrm{C}$, was about 5:1, 7:1, 2:1, respectively. Chokeberries' antioxidant activity was correlated with other bioactive components. The total antioxidant reduction is around 70-80\%.

It can be observed that increasing the drying temperature statistically significantly affects the reduction content of bioactive components. The highest reduction ratio could be seen by comparing the bioactive component content in fresh chokeberry and chokeberries dried at $50{ }^{\circ} \mathrm{C}$. The opposite trend, the lowest reduction in bioactive component contents, might be observed at drying temperatures

Table 2 Total anthocyanins $(T A C)$, flavonoids $(T F C)$, phenols $(T P C)$, and antioxidant activity $(A A)$ of fresh and dried chokeberries

\begin{tabular}{|c|c|c|c|c|}
\hline Materials & $T A C$ (mg cyn-3-glu / 100 g dm) & $T F C(\mathrm{mg} \mathrm{CE} / 100 \mathrm{~g} \mathrm{dm})$ & $T P C(\mathrm{mg} \mathrm{GAE} / 100 \mathrm{~g} \mathrm{dm})$ & $A A(\mathrm{mg} \mathrm{TE} / 100 \mathrm{~g} \mathrm{dm})$ \\
\hline Fresh chokeberry & $1764.97 \pm 25.16^{\mathrm{a}}$ & $2346.31 \pm 13.66^{\mathrm{a}}$ & $5222.54 \pm 3.43^{\mathrm{a}}$ & $112.14 \pm 2.91^{\mathrm{a}}$ \\
\hline Dried chokeberry $\left(50^{\circ} \mathrm{C}\right)$ & $376.89 \pm 5.73^{b}$ & $1037.19 \pm 3.83^{\mathrm{bc}}$ & $1918.79 \pm 3.26^{\mathrm{b}}$ & $37.11 \pm 0.28^{\mathrm{b}}$ \\
\hline Dried chokeberry $\left(60^{\circ} \mathrm{C}\right)$ & $127.43 \pm 0.72^{\mathrm{c}}$ & $1032.01 \pm 1.66^{\mathrm{c}}$ & $1346.35 \pm 2.67^{\mathrm{c}}$ & $26.93 \pm 1.11^{\mathrm{c}}$ \\
\hline Dried chokeberry $\left(70^{\circ} \mathrm{C}\right)$ & $83.79 \pm 1.18^{\mathrm{d}}$ & $800.07 \pm 3.86^{\mathrm{d}}$ & $1169.39 \pm 6.16^{\mathrm{d}}$ & $22.10 \pm 0.92^{\mathrm{d}}$ \\
\hline
\end{tabular}

${ }^{\mathrm{a}-\mathrm{d}}$ Different letters in the superscript in the same column of the table indicate on the statistical significant difference between values at the level of significance of $p<0.05$ (based on post-hoc Tukey HSD test) 
of $60^{\circ} \mathrm{C}$ and $70^{\circ} \mathrm{C}$. The reason might be in a longer period of the drying process and/or a shorter temperature effect.

\subsection{Total rehydration ratio and water absorption capacity}

Effect of temperature on the properties and quantity of absorbed water by chokeberry was evident [32]. Total rehydration ratio and water absorption capacity of dried chokeberries are shown in Table 3.

Dried fruits of chokeberries had rehydration capacity between 1.77 and 1.93 (Table 3). Increasing the temperature of the drying process, the total rehydration capacity was increased. With an increase in the temperature, the surface area of sorption was decreased. These results are in agreement with results obtained by Červenka [32], in which increasing the surface area enhanced the water adsorption, since more polar groups and carbonyl functions of peptide bound were exposed. Generally, the ANOVA test showed that dehydration temperatures $\left(50,60,70{ }^{\circ} \mathrm{C}\right)$ showed minor influence on the capillary spaces in the chokeberries, which explains the great power of re-absorption capacity.

\subsection{Results of sensory characteristics of bread quality}

Bread made of wheat flour had a low antioxidant capacity [33]. Previous studies suggested potential benefits by using the fruits (blueberry, grape, blackcurrant and raspberry) in the formulation of bakery products, as a

Table 3 Total rehydration ratio and water absorption capacity of fresh

\begin{tabular}{lccc}
\multicolumn{4}{c}{ and dried chokeberries } \\
\hline Coefficient & $\begin{array}{c}\text { Dried } \\
\text { chokeberry } \\
\left(50{ }^{\circ} \mathrm{C}\right)\end{array}$ & $\begin{array}{c}\text { Dried } \\
\text { chokeberry } \\
\left(60^{\circ} \mathrm{C}\right)\end{array}$ & $\begin{array}{c}\text { Dried } \\
\text { chokeberry } \\
\left(70{ }^{\circ} \mathrm{C}\right)\end{array}$ \\
\hline$R_{r}$ & $1.77 \pm 0.02^{\mathrm{a}}$ & $1.87 \pm 0.08^{\mathrm{a}}$ & $1.93 \pm 0.07^{\mathrm{a}}$ \\
$C_{r}$ & $38.40 \pm 0.35^{\mathrm{a}}$ & $40.64 \pm 1.84^{\mathrm{a}}$ & $41.79 \pm 1.42^{\mathrm{a}}$ \\
\hline
\end{tabular}

${ }^{a}$ The same letters in the superscript in the same row of the table indicate on lack of statistical significant difference between values at the level of significance of $p<0.05$ (based on post-hoc Tukey HSD test) raw ingredient. Therefore, the primary effect of chokeberry powder is food coloring (sensory characteristic), while the secondary effect is a functional characteristic. Anthocyanins were responsible for the purple color of bread with chokeberry phenol extracts. The other color mechanism was a consequence of Maillard reactions and caramelization $[34,35]$.

The cross-section of the final product (bread) is shown in Fig. 2. Since the content of total bioactive components in chokeberry powders was reduced by about $80 \%$, their content was not determined in the final product, due to the extreme baking $\left(220-250{ }^{\circ} \mathrm{C}\right)$. The primary result of wheat substitution with chokeberry powders was food coloring and maintenance of bread freshness. It was found that the antioxidant activity in bakery products is strongly dependent on manufacturing conditions (high baking temperatures, the formation of indigestible complexes with bread proteins or starch) and recipes (type and fruit concentration) [33].

All types of bread had satisfying quality and could be placed on the market since they achieved a condition that the total number of points exceeds 40 (Table 4).

The best sensory characteristics had bread with dried chokeberry powder produced at $50{ }^{\circ} \mathrm{C}$, due to the preservation of colored substances, fruit acids and aromatic compounds more than other bread. This bread had also
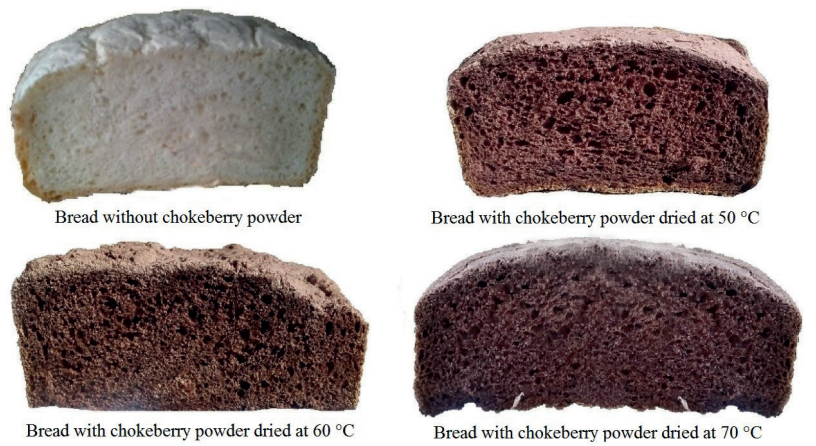

Fig. 2 The cross-section of bread without and with chokeberry powder obtained at different drying temperatures

Table 4 The scoring method of bread without and with chokeberry powder obtained at different drying temperatures

\begin{tabular}{|c|c|c|c|c|}
\hline & $\begin{array}{c}\text { Bread without chokeberry } \\
\text { powder }\end{array}$ & $\begin{array}{c}\text { Bread with chokeberry } \\
\text { powder produced at } 50^{\circ} \mathrm{C}\end{array}$ & $\begin{array}{c}\text { Bread with chokeberry } \\
\text { powder produced at } 60^{\circ} \mathrm{C}\end{array}$ & $\begin{array}{c}\text { Bread with chokeberry } \\
\text { powder produced at } 70^{\circ} \mathrm{C}\end{array}$ \\
\hline Volume & $3.08 \pm 0.38^{\mathrm{ab}}$ & $3.50 \pm 0.84^{\mathrm{b}}$ & $2.00 \pm 0.00^{\mathrm{a}}$ & $2.17 \pm 0.41^{\mathrm{a}}$ \\
\hline Appearance & $4.92 \pm 0.20^{\mathrm{b}}$ & $4.33 \pm 0.75^{b}$ & $2.67 \pm 0.68^{\mathrm{a}}$ & $2.92 \pm 0.20^{\mathrm{a}}$ \\
\hline Texture (mouthfeel, by finger) & $3.08 \pm 0.38^{\mathrm{a}}$ & $3.67 \pm 1.03^{\mathrm{a}}$ & $2.42 \pm 0.80^{\mathrm{a}}$ & $3.83 \pm 0.41^{\mathrm{a}}$ \\
\hline Mid and crust bread flavor & $4.92 \pm 0.20^{\mathrm{a}}$ & $4.42 \pm 0.92^{\mathrm{a}}$ & $3.25 \pm 1.25^{\mathrm{a}}$ & $3.83 \pm 0.98^{\mathrm{a}}$ \\
\hline Mid and crust bread taste & $4.92 \pm 0.20^{\mathrm{a}}$ & $4.67 \pm 0.52^{\mathrm{a}}$ & $3.42 \pm 1.02^{\mathrm{a}}$ & $4.08 \pm 0.66^{\mathrm{a}}$ \\
\hline Total score $(\Sigma)$ & $82.00 \pm 0.27^{\mathrm{a}}$ & $81.95 \pm 0.81^{\mathrm{a}}$ & $54.96 \pm 0.75^{\mathrm{b}}$ & $68.48 \pm 0.53^{\mathrm{c}}$ \\
\hline
\end{tabular}

${ }^{\mathrm{a}-\mathrm{c}}$ Different letters in the superscript in the same row of the table indicate on the statistical significant difference between values at the level of significance of $p<0.05$ (based on post-hoc Tukey HSD test) 
the most homogeneous texture and uniformity of the mid pores, without large bubbles and volume (Fig. 2), due to a higher quality chokeberry powder. The greatest bread volume might be caused by the smallest rehydration ratio and water absorption capacity of dried chokeberries at $50{ }^{\circ} \mathrm{C}$.

Sensory characteristics, such as flavor and taste, as well as the surface appearance of the bread, were rated with the highest average score. Therefore, it could be concluded that these parameters proved to be the dominant and most influential ones when the sensory characteristics were determinate, especially by the consumers. It can be seen that increasing the drying temperature statistically significantly affects the reduction of all sensory characteristics.

QDA method was an adequate method in monitoring the quality of the final product (i.e. bread) in the industry (Fig. 3, Table 4). As the area on QDA diagram was larger, the quality of the final product was higher. Bread with chokeberry powder produced by chokeberry dried at $50{ }^{\circ} \mathrm{C}$ had the best sensory quality (the largest QDA area). Increasing the drying temperature up to $60^{\circ} \mathrm{C}$ and $70{ }^{\circ} \mathrm{C}$, decreased the sensory quality of chokeberry powder and sensory quality of bread. QDA method is in a strong correlation to the scoring method, in which the bread with chokeberry powder produced by drying at $50{ }^{\circ} \mathrm{C}$ had the highest average score. Based on the layout of the QDA diagram, QDA method is a quick qualitative method that can be used in industrial production.

\section{Conclusions}

The chokeberry convective drying kinetics was successfully described by the Henderson \& Pabis and GaussMod models. The recommended drying method was convective drying at $50{ }^{\circ} \mathrm{C}$. It showed the highest total content of bioactive components (anthocyanins, flavonoids and phenols) and antioxidant activity and produced the chokeberry powder which would make the bread with the best sensory characteristics. The drying process at $70{ }^{\circ} \mathrm{C}$ is the alternative method, which

\section{References}

[1] Lee, Y.-L., Yen, M.-T., Mau, J.-L. "Antioxidant properties of various extracts from Hypsizigus marmoreus", Food Chemistry, 104(1), pp. 1-9, 2007.

https://doi.org/10.1016/j.foodchem.2006.10.063

[2] Kim, H. G., Kim, G.-S., Park, S., Lee, J. H., Seo, O. N., Lee, S. J., Kim, J. H.,Shim, J.-H., El-Aty, A. M. A., Jin, J. S., Shin, S. C. "Flavonoid profiling in three citrus varieties native to the Republic of Korea using liquid chromatography coupled with tandem mass spectrometry: Contribution to overall antioxidant activity", Biomedical Chromatography, 26(4), pp. 464-470, 2012. https://doi.org/10.1002/bmc.1688

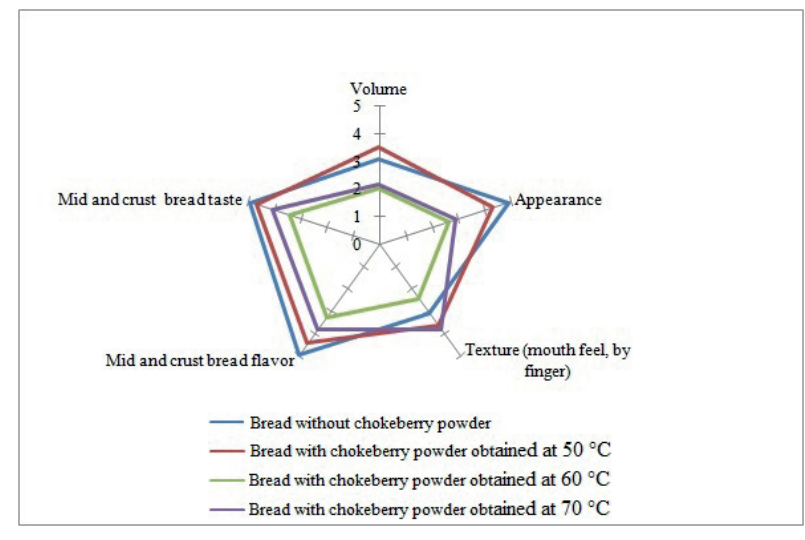

Fig. 3 QDA diagrams of bread without and with chokeberry powder obtained at different drying temperatures

would make the bread with very good sensory characteristics and lower values of total bioactive components.

The reducing ratio of antioxidant activity shows that the anthocyanins are the most degraded (4 to 7 times more degraded relative to phenols, flavonoids, and antioxidativity).

The addition of chokeberry powders would lead to changes within the bread sensory characteristics, especially volume and appearance (color), flavor and taste. These products can be commercially produced. Unfortunately, the content of total bioactive components, after drying and pre-baking process, was reduced up to $80 \%$. Therefore, the attempts to increase the antioxidants content in bread and developing functional bread would be a technical challenge. Future experiments will include studies based on dehydration methods of chokeberry (such as lyophilization) and dehydration parameters (vacuum, low-temperature ratio, methods of fruit preparation), applied to a wider of confectionery products.

\section{Acknowledgment}

This work is supported by the Ministry of Education, Science and Technological Development of the Republic of Serbia (project numbers OI-172016 and OI-172057).

[3] Ho, G. T. T., Bräunlich, M., Austarheim, I., Wangensteen, H., Malterud, K. E., Slimestad, R., Barsett, H. "Immunomodulating Activity of Aronia melanocarpa Polyphenols", International Journal of Molecular Sciences, 15(7), pp. 11626-11636, 2014. https://oi.org/10.3390/ijms150711626

[4] Janković, B., Marinović-Cincović, M., Janković, M. "Isoconversional kinetic study and accurate determination of lifetime properties for thermal and thermo-oxidative degradation processes of Aronia melanocarpa", Innovative Food Science and Emerging Technologies, 33, pp. 542-553, 2016. https://doi.org/10.1016/j.ifset.2015.10.016 
[5] Oszmiański, J., Wojdylo, A. "Aronia melanocarpa phenolics and their antioxidant activity", European Food Research and Technology, 221(6), pp. 809-813, 2005.

https://doi.org/10.1007/s00217-005-0002-5

[6] Kokotkiewicz, A., Jaremicz, Z., Luczkiewicz, M. "Aronia Plants: A Review of Traditional Use, Biological Activities, and Perspectives for Modern Medicine", Journal of Medicinal Food, 13(2), pp. 255-269, 2010.

https://doi.org/10.1089/jmf.2009.0062

[7] Camire, M. E., Dougherty, M. P., Briggs, J. L. "Functionality of fruit powders in extruded corn breakfast cereals", Food Chemistry, 101(2), pp. 765-770, 2007.

https://doi.org/10.1016/j.foodchem.2006.02.031

[8] Leong, S. Y., Oey, I. "Effects of processing on anthocyanins, carotenoids and vitamin $\mathrm{C}$ in summer fruits and vegetables", Food Chemistry, 133(4), pp. 1577-1587, 2012.

https://doi.org/10.1016/j.foodchem.2012.02.052

[9] Guajardo-Flores, D., Rempel, C., Gutiérrez-Uribe, J. A., SernaSaldívar, S. O. "Influence of Excipients and Spray Drying on the Physical and Chemical Properties of Nutraceutical Capsules Containing Phytochemicals from Black Bean Extract", Molecules, 20(12), pp. 21626-21635, 2015.

https://oi.org/10.3390/molecules201219792

[10] Gawałek, J., Domian, E., Ryniecki, A., Bakier, S. "Effects of the spray drying conditions of chokeberry (Aronia melanocarpa L.) juice concentrate on the physicochemical properties of powders", International Journal of Food Science and Technology, 52(9), pp. 1933-1941, 2017.

https://doi.org/10.1111/ijfs.13476

[11] Rice-Evans, C. A., Miller, N. J., Paganga, G. "Structureantioxidant activity relationships of flavonoids and phenolic acids", Free Radical Biology and Medicine, 20(7), pp. 933-956, 1996. https://doi.org/10.1016/0891-5849(95)02227-9

[12] Peressini, D., Sensidoni, A. "Effect of soluble dietary fibre addition on rheological and breadmaking properties of wheat doughs", Journal of Cereal Science, 49(2), pp. 190-201, 2009. https://doi.org/10.1016/j.jcs.2008.09.007

[13] Oszmiański, J., Lachowicz, S. "Effect of the Production of Dried Fruits and Juice from Chokeberry (Aronia melanocarpa L.) on the Content and Antioxidative Activity of Bioactive Compounds", Molecules, 21(8), article ID: 1098, 2016.

https://doi.org/10.3390/molecules21081098

[14] Szychowski, P. J., Lech, K., Sendra-Nadal, E., Hernández, F., Figiel, A., Wojdyło, A., Carbonell-Barrachina, Á. A. "Kinetics, biocompounds, antioxidant activity, and sensory attributes of quinces as affected by drying method", Food Chemistry, 255, pp. 157-164, 2018.

https://doi.org/10.1016/j.foodchem.2018.02.075

[15] Mitrović, О. V. "КИНЕТИКА СУШЕЊА И КВАЛИТЕТ СУШЕНИХ ПЛОДОВА НАЈЗНАЧАЈНИЈИХ СОРАТА ШљИВА У СРБИЈИ", (Drying kinetics and quality of dried fruits of major plum cultivars grown in Serbia) $\mathrm{PhD}$ Thesis, University of Belgrade, 2012. [online] Available at: http://nardus.mpn.gov.rs/handle/123456789/2555?locale-attribute=sr_RS [Accessed: 18 December 2018] (in Serbian)
[16] Tanner, H., Brunner, H. R. "Gentränke-Analytik: Untersuchungsmethoden für die Labor- und Betriebspraxis", (Beverage Analysis: Investigation Methods For Laboratory and Operational Practice) 1st ed., Verlag Heller Chemie und Verwaltunsgesellschaft GmbH, Schwäbisch Hall, Germany, 1979. (in German)

[17] Prior, R. L., Cao, G., Martin, A., Sofic, E., McEwen, J., O'Brien, C., Lischner, N., Ehlenfeldt, M., Kalt, W., Krewer, G., Mainland, C. M. "Antioxidant Capacity As Influenced by Total Phenolic and Anthocyanin Content, Maturity, and Variety of Vaccinium Species", Journal of Agricultural and Food Chemistry, 46(7), pp. 2686-2693, 1998.

https://doi.org/10.1021/jf980145d

[18] Liu, M., Li, X. Q., Weber, C., Lee, C. Y., Brown, J., Liu, R. H. "Antioxidant and Antiproliferative Activities of Raspberries", Journal of Agricultural and Food Chemistry, 50(10), pp. 2926-2930, 2002.

https://doi.org/10.1021/jf0111209

[19] Re, R., Pellegrini, N., Proteggente, A., Pannala, A., Yang, M., Rice-Evans, C. "Antioxidant activity applying an improved ABTS radical cation decolorization assay", Free Radical Biology and Medicine, 26(9-10), pp. 1231-1237, 1999.

https://doi.org/10.1016/S0891-5849(98)00315-3

[20] Dauthy, M. E. "Fruit drying and dehydration technology", In: Fruit and Vegetable Processing, FAO Agricultural Services Bulletin, vol. 119, Food and Agriculture Organization of the United Nations, Rome, Italy, 1995, pp. 309-311. [online] Available at http://www.fao. org/docrep/V5030E/V5030E00.htm [Accessed: 03 January 2019]

[21] Kaluđerski, G., Filipović, N. "Metode laboratorijskog pečenja" (Methods of laboratory baking), In: Žeželj, M., Vukobratović, R. (eds.) Methods of testing the quality of cereals, flour and finished products, 1st ed., Faculty of Technology, Novi Sad, Serbia, 1998, pp. 253-256. (in Serbian) [online] Available at: https://www.tehnologijahrane.com/knjiga/metode-ispitivanja-kvaliteta-zita-brasna-i-gotovih-proizvoda [Accessed:03 January 2019]

[22] International Organization for Standardization "ISO 4121:2003 Sensory analyses - Guidelines for the use of quantitative response scales", ISO, Geneva, Switzerland, 2003. [online] Available at: https://www.iso.org/standard/33817.html [Accessed: 03 January 2019]

[23] StatSoft Inc. "STATISTICA Data Analysis Software System, (Version 10)", [computer program] Available at: https://statistica. software.informer.com/10.0/ [Accessed: 15 December 2018]

[24] Calín-Sánchez, Á., Kharaghani, A., Lech, K., Figiel, A., Carbonell-Barrachina, Á. A., Tsotsas, E. "Drying Kinetics and Microstructural and Sensory Properties of Black Chokeberry (Aronia melanocarpa) as Affected by Drying Method", Food and Bioprocess Technology, 8(1), pp. 63-74, 2015. https://doi.org/10.1007/s11947-014-1383-x

[25] Liepiņa, I., Nikolajeva, V., Jākobsone, I. "Antimicrobial activity of extracts from fruits of Aronia melanocarpa and Sorbus aucuparia", Environmental and Experimental Biology, 11(4), pp. 195-199, 2013. [online] Available at: http://eeb.lu.lv/EEB/201312/EEB_11_Liepina. pdf [Accessed: 03 January 2019] 
[26] Horszwald, A., Julien, H., Andlauer, W. "Characterisation of Aronia powders obtained by different drying processes", Food Chemistry, 141(3), pp. 2858-2863, 2013.

https://doi.org/10.1016/j.foodchem.2013.05.103

[27] Samoticha, J., Wojdyło, A., Lech, K. "The influence of different the drying methods on chemical composition and antioxidant activity in chokeberries", LWT - Food Science and Technology, 66, pp. 484-489, 2016.

https://doi.org/10.1016/j.lwt.2015.10.073

[28] Ioannou, I., Ghoul, M. "5 Biological Activities and Effects of Food Processing on Flavonoids as Phenolic Antioxidants", In: Petre, M. (ed.) Advances in Applied Biotechnology, IntechOpen Limited, Rijeka, Croatia, 2012, pp. 101-124. https://doi.org/10.5772/30690

[29] Lee, J. E., Kim, G.-S., Park, S., Kim, Y. H., Kim, M. B., Lee, W. S., Jeong, S. W., Lee, S. J., Jin, J. S., Shin, S. C. "Determination of chokeberry (Aronia melanocarpa) polyphenol components using liquid chromatography-tandem mass spectrometry: Overall contribution to antioxidant activity", Food Chemistry, 146, pp. 1-5, 2014. https://doi.org/10.1016/j.foodchem.2013.09.029

[30] Jakobek, L., Šeruga, M., Medvidović-Kosanović, M., Novak, I. "Antioxidant Activity and Polyphenols of Aronia in Comparison to other Berry Species", Agriculturae Conspectus Scientificus, 72(4), pp. 301-306, 2007. [online] Available at: https://hrcak.srce. hr/19396 [Accessed: 03 January 2019]

[31] Takashima, M., Horie, M., Shichiri, M., Hagihara, Y., Yoshida, Y., Niki, E. "Assessment of antioxidant capacity for scavenging free radicals in vitro: A rational basis and practical application", Free Radical Biology and Medicine, 52(7), pp. 1242-1252, 2012. https://doi.org/10.1016/j.freeradbiomed.2012.01.010
[32] Črvenka, L. "Moisture Adsorption Characteristics of Black Currant (Ribes nigrum L.), Black Elderberry (Sambucus nigra L.) and Chokeberry (Aronia melanocarpa, [MINCHX.] ELL.) Samples at Different Temperatures", Journal of Food Process Engineering, 34(5), pp. 1419-1434, 2011. https://doi.org/10.1111/j.1745-4530.2009.00507.x

[33] Dziki, D., Różyło, R., Gawlik-Dziki, U., Świeca, M. "Current trends in the enhancement of antioxidant activity of wheat bread by the addition of plant materials rich in phenolic compounds", Trends in Food Science and Technology, 40(1), pp. 48-61, 2014.

https://doi.org/10.1016/j.tifs.2014.07.010

[34] Rohm, H., Brennan, C., Turner, C., Günther, E., Campbell, G., Hernando, I., Struck, S., Kontogiorgos, V. "Adding Value to Fruit Processing Waste: Innovative Ways to Incorporate Fibers from Berry Pomace in Baked and Extruded Cereal-based Foods-A SUSFOOD Project", Foods, 4(4), pp. 690-697, 2015. https://doi.org/10.3390/foods4040690

[35] Schmidt, C., Geweke, I., Struck, S., Zahn, S., Rohm, H. "Blackcurrant pomace from juice processing as partial flour substitute in savoury crackers: dough characteristics and product properties", International Journal of Food Science and Technology, 53(1), pp. 237-245, 2018.

https://doi.org/10.1111/ijfs.13639 